\title{
Reward Management Practices and Employee Performance of Public Universities in South-East, Nigeria
}

\author{
Okoli I., Okoli D., and Nuel-Okoli C.
}

\begin{abstract}
The purpose of the paper was to examine the relationship that exists between Reward Management Practices and Employee Performance in selected Public Universities in the South-East Nigeria. The paper was anchored on Equity Theory. A descriptive survey research design was adopted by the study. Stratified sampling techniques were used to obtain a sample of 365 out of a target population of 7411 using Krejcie and Morgan (1970) formula. Data were collected using a structured questionnaire. The questionnaire was tested for reliability by using Split half test to determine the internal consistency of the items. The paper used expert judgment method to determine content validity. Data were analyzed using Pearson's Product Moment Correlation Coefficient (PPMCC) at .05 level of significance. The findings revealed that there was a significant positive relationship existing between distributive justice and employee commitment (cal. $\mathbf{r} .893$ > crit. $\mathbf{r} 0.098$ ) and there was a significant positive relationship existing between employee recognition and job satisfaction (cal. r $.942>$ crit. $r$ 0.098). It was hence recommended among other things that the focused public universities need to ensure that employees are rewarded justly and fairly and that they need not rely solely on the base pay employee earn but also inculcate several recognition programs into their reward systems.
\end{abstract}

Index Terms-Employees performance, Equity Theory, Reward Management, Reward System.

\section{INTRODUCTION}

Organizations like the public universities in the Southeast Nigeria are made up of people from different background, different views about life, different expectations and different mind sets. These group of people are brought together to ensure that the institutions mandate of producing quality graduates to drive the affairs of not just the country but that of the world is achieved [52]. Achieving this depends on the employees and their level of commitment and commitment to the organization. Reference [51] posits that commitment is crucial to making employees to be identified, attached and be involved in organizational goals. The performance of any university system depends, to a large extent, upon how her employees are rewarded, utilized and provided with adequate and conducive environment to perform their duties [53]. In other words, employees are the basis of the very existence of any organization. Reference [9] state that employee performance has been a concern for

Published on June 5, 2020.

Ifeanyi Okoli, Nnamdi Azikiwe University, Nigeria.

(e-mail: eokoli76@yahoo.com)

David Okoli, Nigeria

(e-mail: daveoko2003@gmail.com)

Chinenye Nuel-Okoli, Nigeria.

(e-mail: chinnynuel@yahoo.com). organizations in today's competitive environment, as it is now commonly accepted that employees create an important source of competitive advantage for companies. The willingness of employees to use their imagination, skills and knowledge influences the success of an organization [63]. Corroborating this position, [57] affirm that workers are assets of a company and are the brains through which the whole process in an organization comes to life.

Having recognized the prominent role played by employee organizations, employees are now considered the backbone of corporate survival. The reward has to do with what employees receive in exchange for their contribution to an organization; it could also be a form of positive reinforcement and motivation. It is what an employee expects to get after performing work in days, months or years in cash or in kind. [61] State that the reward is the appreciation in cash or in kind given to employees for their contributions to the organization. Therefore, the reward is seen as an exchange relationship between an employee or group of employees and an organization. Reference [44], considers the reward as an exchange strategy. They state that: "Employees can see the reward as a return in exchange between their employer and themselves, as a right to be an employee of the company, or as a reward for a job well done." The reward falls within what is called job exchange [58].

Reward management has to do with the development, implementation and evaluation of reward systems within an organization. Reference [11] believe that rewards management deals with the processes of development, implementation, operation and evaluation of rewards policies and practices that recognize and value people according to the efforts and contributions they make to achieve organizational, departmental and team goals. The reward in organizations covers financial and non-financial aspects, tangible and intangible aspects instead of the erroneous views that the reward has to do only with compensation.

Many reasons are cited for why people decide to work in an organization like the universities studied against working on their own or working in other sectors of the economy. Standing above any other reason, since existing literature argues is a reward; what employees can get in the form of salaries, salaries, complementary benefits, incentives and other forms of emoluments and recognition. The reward is an attractive, motivating and retention factor in most organizations, of which the selected universities are no exception. However, when the rewards system and its management do not act as a positive factor in the organization, it is said that the rewards system is defective or ineffective as it seems in the institutions studied. 
Reference [15] believe that workers are poor rewards packages as an act of injustice in the system that makes the employees feel unhappy with their jobs causing lack of commitment, which affects their overall performance. For its part, [36] points out that, as a result of inadequate rewards management, universities have suffered low performance, low staff morale and high employee turnover.

The employees of organizations seem to be very interested in what they receive and compare it with their effort, if it is proportional, then there is not much problem, but when the opposite happens; when they perceive that what they contribute far exceeds what they get from the organization and its administration, then there is a problem with the rewards management system and this could affect employee performance in the sense that they could lose their commitment to the organization and this could affect the performance of the organization in general. Many studies have also been carried out on reward management practices and employee performance; some of the studies found a significant positive effect between reward management practices and employee performance. Despite the above results, some researchers found a negative effect between reward management practices and employee performance. The results from the empirical studies are inconsistent and some are contradictory, ranging from positive to insignificant negative relationship. Besides, there is a limited study of this nature among public universities in Southeast Nigeria and this created a gap in the literature which this study becomes significant. It is in the context of these problems that this study was necessary to carry out an empirical study of the situation in order to determine how the reward management practices of the institutions studied affect the performance of employees that invariably affect the performance of the organization. Specifically, the study seeks to:

a) Ascertain the relationship existing between distributive justice and employee commitment in the public universities in South- East Nigeria.

b) Examine the relationship existing between employee recognition and job satisfaction in public universities in the South-East Nigeria.

\section{REVIEW OF RELATED LITERATURE}

\section{A. Conceptual framework}

\section{1) Reward Management}

Reference [14] viewed rewards as "all cash, non-cash and psychological payments provided by an organization in exchange for their contribution. "Explaining the reward component, [27] opined that the rewards include compensation (consisting of base salary, short and long-term incentives), benefits (health, work / life and other benefits) and careers (training and development, professional progression). According to [3] reward management is the process of developing and implementing strategies, policies and systems that help the organization succeed in terms of its objectives by attracting and maintaining the people it needs and increasing your motivation and commitment. Reference [7] argues that rewards management is concerned with the development of appropriate organizational cultures, emphasizing core values and improving employee motivation and commitment. Rewards management is not only about designing or developing rewards strategies or policies, it is also about seeing that it is implemented fairly and equitably and evaluating them to see if any improvement, addition or reduction is required to improve the process and help to performance [9]. Reward management can be used as a tool not only to motivate and ensure employee engagement, but also to manage the expectations that employees place in the employer or in the organization and vice versa [46].

The reward can be generally classified in two, extrinsic and intrinsic reward. Extrinsic rewards are the tangible rewards that can be given physically to employees. The organization can provide them directly to employees through salaries and incentives or indirectly through contributions made to employee benefit plans, such as medical benefits and life insurance [60]. Extrinsic rewards include promotions, private office spaces and the social climate, competitive salaries, merit bonuses [41], [30]. Intrinsic rewards are the intangible rewards that employees experience in doing their job, such as the feeling of satisfaction, participation, growth, autonomy and selfcompetence [5].

\section{2) Distributive Justice}

Reference [18] opined that distributive justice is rooted in the theory of equity. According to equity theorists, individuals compare a proportion of their perceived inputs with the results derived from a relationship with that of a referent. If the proportions are equal, the individual perceives distributive justice. If the proportions are unequal, the individual will perceive the inequity [31]. Thus, distributive justice refers to employees' perception concerning whether benefits are distributed fairly or not [20]. According to [26], distributive justice is that form of organizational justice that focuses on people's belief, that their workers will receive fairness in the amounts of valued work with similar outcomes (e.g. Pay, motivation, etc.). Distributive justice requires that rights, benefits, and responsibilities are distributed on the basis of skills and contributions. [17], argued that distributive justice is concerned with the reality that not all workers are treated alike, and that the allocation of outcome is differentiated in workplace.

The management of reward practices in organizations has a lot to do with equity. If employees do not perceive that the rewards are fair, the reward practices and processes could end in a fiasco. Reference [42] corroborates this statement when he affirms that the management of rewards can be achieved by developing and implementing strategies, policies, processes, and practices with the help of principles such as the philosophy of reward, justice in distributive justice, equity, equity, consistency, and transparency. The reward is considered effective when they are fair. This implies building in transparency regarding information on how the reward system works and how employees are rewarded [50].

\section{3) Employees Recognition}

Recognition is one of the most effective and efficient reward strategies used by organizations to motivate workers. Reference [39], State that recognition plays an imperative 
role in motivating employees and improving performance. For [50] explain that recognition and appreciation are other integral components of a winning strategic reward system. One of the most powerful motivations is recognition and it is necessary because people need to know not only how well they have achieved their goals, but also that their achievements are appreciated [50]. Recognition can have an effect on job satisfaction and teacher motivation [45]. A number of research studies indicate that non-financial rewards, such as recognition and other intrinsic rewards are a sine qua non condition for job satisfaction [48].

According to [25], recognition implies praise or a personal note that recognizes achievements, including small gestures that are important to employees. A meaningful, reflective appreciation program employee is about valuing employee efforts and respecting who they are and what they do [28]. Recognition is a leadership tool that sends a message to employees about what is important for leaders and behaviours to be valued. It is to recognize someone before their peers for the desired behaviour or even for the achievements, actions taken or having a positive attitude effect [50].

Reference [4] believes that employees not only want attractive salaries and benefits, but also expect their efforts to be valued, appreciated, and treated fairly. Employees respond to the appreciation expressed through recognition of one's good work because it confirms that one's work is valued. When employees and their work are valued, their satisfaction and productivity increase, and they are motivated to maintain or improve their good work [56]. The measures of effective recognition can also include verbal and written praise, praise and symbolic public gestures by managers [49], [64]. However, money itself is not granted to recognize performance [21]. Praise is probably the most common form of recognition, but there are other forms of recognition, such as long service awards, status symbols of one kind or another; sabbatical and work trips abroad, all of which can be part of the total reward process. Reference [48] concludes that recognition leads to better communication, better cooperation and a decrease in absenteeism and rotation. It can motivate by helping to generate feelings of trust and satisfaction [34] and inspire loyalty and commitment, as well as encouraging employees to extend their efforts [55].

\section{4) Employee Performance}

Reference [10] affirmed that performance is seen as the behaviour that achieves results. Here, the emphasis is on employees and their actions and inactions to get results; thus the importance of evaluating the concept of employee performance. Employee performance is a record of the results obtained from the specific job functions for a certain period of employee [13], [22], postulate that employee performance is the competence of an employee to use the resources of an organisation efficiently and effectively to ensure that the objectives of the organization are achieved. Reference [29] postulates that the measure of employee performance is the determination of finances, profitability and growth attributed to the individual employee as a contribution to the organisation. Employee's performance has become critically the essence and the value to achieve the goals and results of organizational performance; that is, the performance of employees has a correlation with the overall performance of the organization [35]. However, the effectiveness and efficiency with which employees carry out organisational activities assigned depends on many factors as; motivation, commitment, level of satisfaction, which is influenced by the way employees are compensated or rewarded for their effort [6].

\section{B. Employee commitment and Job satisfaction as Dimensions of employee's performance}

\section{1) Employee Commitment}

Reference [8] opines that employee commitment is the loyalty and attachment that employees have in an organization and is associated with their feelings about the institution. It implies the dedication of employees and the willingness to make an effort on behalf of an organization [40]. Organisational commitment is refers to the degree to which a person identifies and feel part of an organization [59].

An employee who has a greater organizational commitment is considered very loyal, which useful to the organizational in terms of increase productivity, quality of work life, better employee morale, decrease turnover and more willingness of employees to exert additional effort. Employer's commitment in employees through reward systems is crucial to attract, motivate and retain the human capital necessary for corporate success [62]. Reference [5] developed a measure of organizational commitment with three main components:

a) The affective component of the commitment that refers to emotional attachment, identification and participation of employees in the organization;

b) Continuance component that refers to the costbased commitment that employees associate with leaving the organization;

c) The normative commitment, which reflects the feeling of an employee's obligation to remain with the organization.

Reference [32] opined that reward management systems influence the efficiency of an organization and also help one achieve their goals by increasing motivation and commitment. Properly grasped [8], believes that when the rewards are well managed, the desired commitment is achieved efficiently and effectively, as employees get a sense of mutual benefit.

\section{2) Job Satisfaction}

[60] defined job satisfaction as one's feelings or mood regarding the nature of their work and is a positive emotional feeling, the result of one's evaluation of their work and work experience by comparing between what you expect from your job and what you really get from it, as well as a function of the range of specific satisfactions and dissatisfactions that he / she experiences with respect to the various dimensions of the job. Reference [19] refers to job satisfaction as the general job attitudes of employees. He divided job satisfaction into five major components as including; attitude toward work group, general working conditions, attitudes toward the organization, monetary benefits and attitude toward supervision which he said is intricately connected with the individual's state of mind 
about the work itself and life in general. [55] See job satisfaction as a positive feeling that an individual has about his/her job, based on the evaluation of the characteristics of the job.

In most organizations, poor reward systems lead to less satisfaction and, in turn, produce a very low organizational commitment [16]. Increasingly, organizations are realizing that to take advantage of employee job satisfaction, they must establish a fair balance between the employee's contribution to the organization and the organization's contribution to the employee [62]. Highlighting this point, [54] opines that employees cannot be satisfied with their jobs unless they are motivated by effective reward systems.

\section{Conceptual Framework}

The framework for this study is presented in Figure 1 below that shows the relationship between dependent variable employee's performance and reward management practices as independent variables.

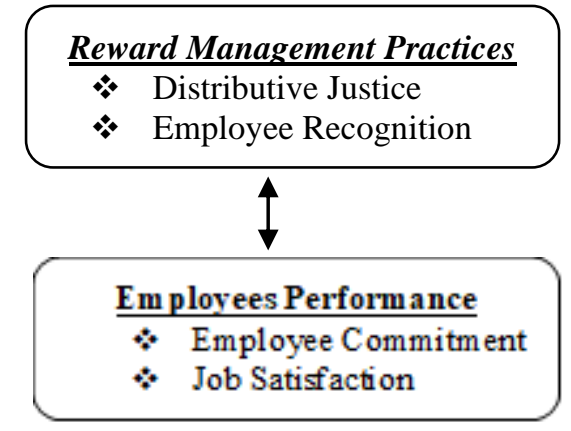

Fig. 1: Conceptual Framework between Reward management practices and Employees Performance

Source: Researcher's Field Survey

Based on the conceptual model, the study proposed the following hypotheses:

Ho1: There is a significant relationship existing between Distributive Justice and Employee Commitment in the selected Public Universities in the South East Nigeria.

Ho2: There is a significant relationship existing between Employee Recognition and Job Satisfaction in the selected Public Universities in the South East Nigeria.

\section{Theoretical Framework}

This study is anchored on Equity theory as proposed by Stacey Adams in 1964. This theory highlights the importance of equity in what is received by the performance or effort made. The equity contained in the theory can be defined as a relationship between the individual's labour contributions and the labour reward. The theory according to [23] is based on the assumption that people, who work for a reward from the organization, are motivated by the desire to receive equal treatment at work and be rewarded. Therefore, the equity here is impartial in terms of comparison of input to output. The theory describes employees' perceptions of what they contribute to the organization, what they get in return, and how their return-to-contribution relationship compares with others inside and outside the organization. This will determine how fair employees perceive their employment relationship [1]. Their efforts must be comparable to the perceived reward to be seen as equitable
$[2]$.

\section{E. Empirical Review}

Reference [63] conducted a study on the influence of intrinsic rewards on organizational performance in public and private sugar companies in western Kenya. The study adopted a descriptive survey research design. The results revealed that there was a positive influence between intrinsic rewards and organizational performance. Therefore, it was recommended that; sugar manufacturing companies should improve their organizational reward systems for employees; they should fully adopt the concept of job training and job rotation to improve employee experience.

Reference [37] examined the effect of financial and nonfinancial rewards on the organizational commitment of employees in Nakuru County universities. The study revealed that there was a moderately significant positive relationship between financial rewards and affective commitment $(r=0.344, p<0.000)$ and a weak significant positive relationship between financial rewards and normative commitment $(\mathrm{r}=0.249, \mathrm{p}<0.008)$. The study found that financial reward management practices collectively have a significant effect on organizational commitment. The study recommended that universities in Nakuru County conduct salary reviews to develop a reward management structure that is externally competitive, internally fair and consistent with current acceptable international rates.

Reference [47] determined the effects of the reward and recognition on the work performance of employees at the University of Kenyatta. The results indicated a significantly positive relationship between reward and recognition, with employee performance. In addition, there was also a very positive and significant relationship between work performance and independent variables (extrinsic rewards, intrinsic rewards and financial rewards, recognition rewards, work environment and leadership styles).

Reference [12] conducted a study on the effects of organizational justice on organizational commitment, focusing only on two dimensions (distributive and procedural justice) of organisational justice. The results revealed that distributive and procedural justice has notable and positive effects on the dependent variable (organizational commitment) of employees.

Reference [4] examined the impact of reward and recognition on job satisfaction and motivation. The variance analysis technique was used to test the hypothesis and it was shown that the rewards had a positive impact on work motivation, but there was no significant relationship between reward and job satisfaction. Again, both academic staff and university administrators perceived the rewards as fair. The challenges faced by the private tertiary sector were lack of funds, pressure from unions and other interest groups, the existence of many qualified people to obtain rewards at a given time along with academic staff emphasizing rewards direct monetary.

Reference [24] examined the impact of distributive and procedural justice on the intention of rotation through affective commitment. The results showed that distributive and procedural justice was significantly and positively related to affective commitment, which in turn was 
significantly and negatively related to the intention of rotation. It was also revealed that the affective commitment fully mediates the relationship between distributive and procedural justice with the intention of billing. The results also showed that the type of organization in which an employee works does not moderate the relationship between the affective commitment and the intention to rotate.

Reference [33] examined the relationship of distributive justice and procedural justice and organizational commitment in the public sector of Pakistan. The results of the linear regression indicated that both distributive and procedural justice have a positive and significant relationship with three constructions of organizational commitment that is identification, affiliation and exchange commitment.

Reference [43] examined the impact of the effective reward system as a tool for the performance of employees in the civil service using the Anambra State Civil Service as a case study. The study adopted a survey design. The Pearson product-moment correlation coefficient and multiple regression analysis were adopted as the most appropriate statistical technique for the study. The results showed that the salary reward and some non-financial rewards of employee recognition, the favourable work environment and staff development are positively and significantly related to the performance of employees in the civil service.

\section{Methodology}

A descriptive survey research design was adopted by this study given that data for the study was collected through questionnaire from sampled respondents. The population of the study consists of all the non-academic staff in the selected universities. The study population from which the sample was drawn for the study consists of three public universities in Southeast, Nigeria namely (Ebonyi State University (EBSU), Federal University of Technology Owerri (FUTO), Nnamdi Azikiwe University, Awka (UNIZIK)).The population of the study depict that EBSU has a total non-academic strength of 2009; FUTO has 2423 while UNIZIK has 2979 making it a total of 7411 staff. The sample size of the study was determined using Krejcie \& Morgan (1970) formula. Respondents were selected using the stratified sampling technique. An initial sample size of $\mathrm{n}=365$ respondents was set, using the available historical information. However, 316 usable questionnaires were eventually collected and used in the data analysis, which gave an acceptable response rate of nearly $86.6 \%$. The data collection instrument was a five-point structured Likert questionnaire. The instrument was subjected to face and content validity to ensure that it measured what was intended. The instrument was subjected to Split-Half reliability technique to ascertain how consistent the instrument is in eliciting data using $20 \%$ (73 copies of the questionnaire) of the sample size. Data analysis was done through the use of Pearson's Product Moment Correlation Coefficient. The level of significance used is 0.05 , this guided the interpretation of correlation results to know whether the result is statistically significant or not. If the pvalue obtained is less than 0.05 ( $\mathrm{p}$-value $<0.05$ ), the alternate hypothesis will be accepted, but if the p-value is greater than 0.05 ( $\mathrm{p}$-value $>0.05$ ), the null hypothesis will be accepted.

\section{DATA PRESENTATION AND ANALYSIS}

\section{A. Research Question One}

What is the nature of relationship existing between Distributive Justice and Employee Commitment in the selected Public Universities in the South East?

TABLE 4.1: Distribution OF RESPONSES FOR DisTRIBUTIVE JUSTICE AND EMPLOYEE COMMITMENT

\begin{tabular}{|c|c|c|c|c|c|c|c|c|}
\hline$S / N$ & $\begin{array}{l}\text { Questionnaire } \\
\text { Items }\end{array}$ & $\begin{array}{l}S A \\
(5)\end{array}$ & $\begin{array}{l}A \\
(4)\end{array}$ & $\begin{array}{l}U D \\
(3)\end{array}$ & $\begin{array}{l}D \\
(2)\end{array}$ & $\begin{array}{l}S D \\
(1)\end{array}$ & Mean & $\begin{array}{l}D \\
e \\
c i \\
s i \\
o \\
n\end{array}$ \\
\hline & $\begin{array}{l}\text { Distributive } \\
\text { Justice }\end{array}$ & & & & & & & \\
\hline 1 & $\begin{array}{l}\text { What I } \\
\text { receive in } \\
\text { form of pay is } \\
\text { comparable } \\
\text { to what I put } \\
\text { into the } \\
\text { organization. }\end{array}$ & 32 & 56 & 10 & 102 & 116 & 2.32 & $\begin{array}{l}R \\
e j \\
e \\
c t\end{array}$ \\
\hline 2 & $\begin{array}{l}\text { I am not } \\
\text { being cheated } \\
\text { when it comes } \\
\text { to rewarding } \\
\text { me in my } \\
\text { organization. }\end{array}$ & 78 & 121 & - & 117 & - & 3.51 & $\begin{array}{l}A \\
c \\
c \\
e \\
p t\end{array}$ \\
\hline 3 & $\begin{array}{l}\text { I am fairly } \\
\text { treated in my } \\
\text { organization } \\
\text { using reward } \\
\text { system as a } \\
\text { measurement } \\
\text { instrument. }\end{array}$ & 12 & 79 & 03 & 90 & 132 & 2.21 & $\begin{array}{l}R \\
e j \\
e \\
c t\end{array}$ \\
\hline 4 & $\begin{array}{l}\text { My } \\
\text { organization } \\
\text { is fair when it } \\
\text { comes to } \\
\text { rewarding me } \\
\text { according to } \\
\text { my } \\
\text { contributions. }\end{array}$ & 32 & 68 & 16 & 101 & 99 & 2.47 & $\begin{array}{l}R \\
e j \\
e \\
c t\end{array}$ \\
\hline 5 & $\begin{array}{l}\text { People that } \\
\text { do the same } \\
\text { kind of jobs in } \\
\text { my } \\
\text { organization } \\
\text { are rewarded } \\
\text { equally. }\end{array}$ & 78 & 25 & 79 & 80 & 54 & 2.98 & $\begin{array}{l}R \\
e j \\
e \\
c t\end{array}$ \\
\hline & $\begin{array}{l}\text { Employee } \\
\text { Commitment }\end{array}$ & & & & & & & \\
\hline 6 & $\begin{array}{l}\text { I will be more } \\
\text { loyal to my } \\
\text { organization } \\
\text { if I am } \\
\text { rewarded } \\
\text { justly. }\end{array}$ & 132 & 163 & - & 21 & - & 3.65 & $\begin{array}{l}A \\
c \\
c \\
e \\
p t\end{array}$ \\
\hline 7 & $\begin{array}{l}\text { How fair my } \\
\text { reward is in } \\
\text { the } \\
\text { organization } \\
\text { determines } \\
\text { how } \\
\text { committed I } \\
\text { am to my } \\
\text { organization. }\end{array}$ & 181 & 70 & 01 & 43 & 21 & 4.10 & $\begin{array}{l}\text { Ac } \\
\text { cep } \\
t\end{array}$ \\
\hline 8 & $\begin{array}{l}I \quad \text { am } \\
\text { motivated to } \\
\text { perform } \\
\text { better in the } \\
\text { organization }\end{array}$ & 79 & 68 & 21 & 130 & 18 & 3.19 & $\begin{array}{l}\text { Ac } \\
\text { cep } \\
t\end{array}$ \\
\hline
\end{tabular}




\begin{tabular}{|c|c|c|c|c|c|c|c|c|}
\hline & $\begin{array}{l}\text { because I am } \\
\text { not cheated } \\
\text { when it comes } \\
\text { to rewarding } \\
\text { performance. }\end{array}$ & & & & & & & \\
\hline 9 & $\begin{array}{l}\text { The reward } \\
\text { system in my } \\
\text { organization } \\
\text { does not } \\
\text { encourage me } \\
\text { to put in extra } \\
\text { effort. }\end{array}$ & 67 & 191 & 08 & 50 & - & 3.87 & $\begin{array}{l}\text { Ac } \\
\text { cep } \\
t\end{array}$ \\
\hline 10 & $\begin{array}{l}\text { I am } \\
\text { discouraged } \\
\text { to perform } \\
\text { well because } \\
\text { what I receive } \\
\text { in return for } \\
\text { my } \\
\text { performance } \\
\text { is not fair. }\end{array}$ & 130 & 131 & - & 55 & - & 4.06 & $\begin{array}{l}\text { Ac } \\
\text { cep } \\
t\end{array}$ \\
\hline
\end{tabular}

\section{B. Research Question Two}

What is the relationship existing between Employee Recognition and Job Satisfaction in the selected Public Universities in the South East?

TABLE 4.2: DISTRIBUTION OF RESPONSES FOR EMPLOYEE RECOGNITION AND JOB SATISFACTION

\begin{tabular}{|c|c|c|c|c|c|c|c|c|}
\hline$S / N$ & $\begin{array}{l}\text { Questionnaire } \\
\text { Items }\end{array}$ & $\begin{array}{l}S A \\
(5)\end{array}$ & $\begin{array}{l}A \\
(4)\end{array}$ & $\begin{array}{l}U D \\
(3)\end{array}$ & $\begin{array}{l}D \\
(2)\end{array}$ & $\begin{array}{l}S D \\
\text { (1) }\end{array}$ & Mean & $\begin{array}{l}\text { De } \\
\text { cisi } \\
\text { on }\end{array}$ \\
\hline & $\begin{array}{l}\text { Employee } \\
\text { Recognition }\end{array}$ & & & & & & & \\
\hline 1 & $\begin{array}{l}\text { Each time I } \\
\text { do a good } \\
\text { job, } \\
\text { organization } \\
\text { acknowledges } \\
\text { it. }\end{array}$ & 43 & 65 & - & 121 & 87 & 2.54 & $\begin{array}{l}\text { Rej } \\
\text { ect }\end{array}$ \\
\hline 2 & $\begin{array}{l}\text { My place of } \\
\text { work } \\
\text { encourages } \\
\text { me to work } \\
\text { harder by } \\
\text { praising good } \\
\text { performers. }\end{array}$ & 17 & 79 & - & 140 & 80 & 2.41 & $\begin{array}{l}\text { Rej } \\
\text { ect }\end{array}$ \\
\hline 3 & $\begin{array}{l}\text { When you } \\
\text { perform } \\
\text { better than } \\
\text { others in my } \\
\text { organization, } \\
\text { your status } \\
\text { will be made } \\
\text { to improve by } \\
\text { the } \\
\text { organization. }\end{array}$ & - & 101 & 19 & 69 & 127 & 2.30 & $\begin{array}{l}\text { Rej } \\
\text { ect }\end{array}$ \\
\hline 4 & $\begin{array}{l}\text { The reward } \\
\text { system in } \\
\text { place in my } \\
\text { organization } \\
\text { does not } \\
\text { recognize } \\
\text { hardwork. }\end{array}$ & 121 & 87 & 21 & 87 & - & 3.77 & $\begin{array}{l}\text { Acc } \\
\text { ept }\end{array}$ \\
\hline 5 & $\begin{array}{l}\text { There are } \\
\text { formal ways } \\
\text { of } \\
\text { recognizing } \\
\text { people that } \\
\text { exceed } \\
\text { expectations } \\
\text { in terms of } \\
\text { performance } \\
\text { in my } \\
\text { organization. }\end{array}$ & 39 & 60 & 32 & 64 & 121 & 2.47 & $\begin{array}{l}\text { Rej } \\
\text { ect }\end{array}$ \\
\hline
\end{tabular}

\begin{tabular}{|c|c|c|c|c|c|c|c|c|}
\hline & $\begin{array}{l}\text { Job } \\
\text { Satisfaction } \\
\end{array}$ & & & & & & & \\
\hline 6 & $\begin{array}{l}\text { When I am } \\
\text { praised for } \\
\text { better } \\
\text { performance, } \\
\text { it makes me } \\
\text { feel proud of } \\
\text { myselfand my } \\
\text { job. }\end{array}$ & 121 & 156 & 05 & 34 & - & 4.15 & $\begin{array}{l}\text { Acc } \\
\text { ept }\end{array}$ \\
\hline 7 & $\begin{array}{l}\text { I enjoy doing } \\
\text { my work } \\
\text { knowing that } \\
\text { my effort will } \\
\text { be properly } \\
\text { recognized. }\end{array}$ & 43 & 68 & - & 94 & 111 & 2.49 & $\begin{array}{l}R e j \\
e c t\end{array}$ \\
\hline 8 & $\begin{array}{l}\text { If bonuses are } \\
\text { attached to } \\
\text { performance, } \\
\text { my work } \\
\text { experience } \\
\text { will be } \\
\text { enjoyable. }\end{array}$ & 108 & 139 & - & 69 & - & 3.91 & $\begin{array}{l}\text { Acc } \\
\text { ept }\end{array}$ \\
\hline 9 & $\begin{array}{l}\text { The } \\
\text { satisfaction I } \\
\text { derive from } \\
\text { my work } \\
\text { depends on } \\
\text { the } \\
\text { recognition I } \\
\text { receive for } \\
\text { performance. }\end{array}$ & 98 & 118 & - & 72 & 28 & 3.59 & $\begin{array}{l}\text { Acc } \\
\text { ept }\end{array}$ \\
\hline 10 & $\begin{array}{l}\text { I do not enjoy } \\
\text { my job } \\
\text { because my } \\
\text { efforts are not } \\
\text { properly } \\
\text { recognized. } \\
\end{array}$ & 39 & 171 & $9 b$ & 60 & 37 & 3.36 & $\begin{array}{l}\text { Acc } \\
\text { ept }\end{array}$ \\
\hline
\end{tabular}

\section{Test of Hypotheses \\ 1) Hypotheses One}

H1: There is a significant relationship existing between Distributive Justice and Employee Commitment in the selected Public Universities in the South East Nigeria.

TABLE 4.3: CORRELATION ANALYSIS FOR DISTRIBUTIVE JUSTICE AND EMPLOYEE COMMITMENT

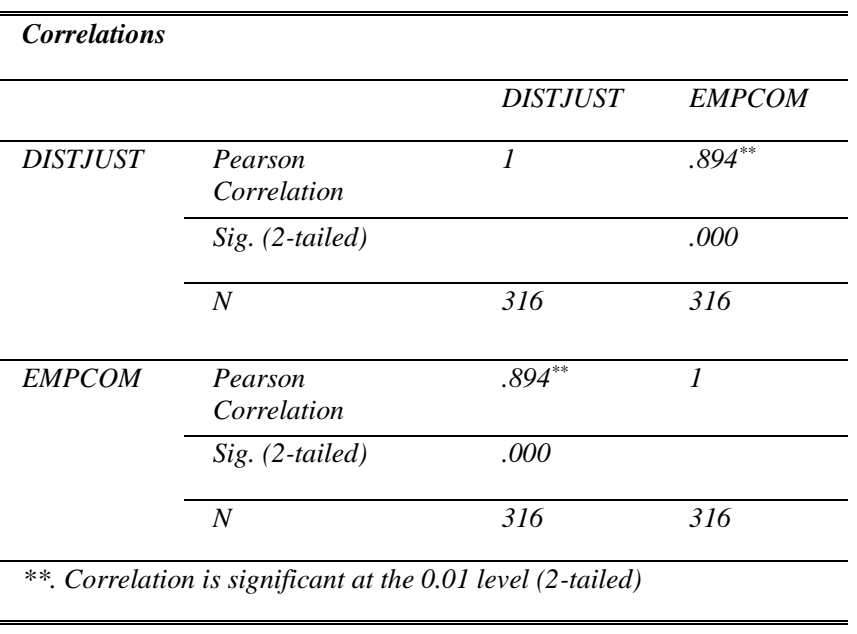

Computation: SPSS Vs 20

Where:

DISTJUST $=$ Distributive Justice

EMPCOM = Employee Commitment

Table 4.3 shows the correlation analysis carried out 
between Distributive Justice and Employee Commitment in the selected Public Universities in the South East, Nigeria. The correlation coefficient obtained was .894 which shows that the relationship is very strong and positive.

TABLE 4.4: SignifiCANCE TEST FOR HyPOTHESIS ONE

\begin{tabular}{lllll}
\hline \hline$N$ & Cal. $R$ & DF & Crit. $r$. & Remark \\
\hline 316 & .894 & 314 & 0.098 & Significant \\
\hline \hline
\end{tabular}

Table 4.4 indicates the test of significance for hypothesis one. It revealed that at .05 level of significance and at 314 degrees of freedom, that the critical $r$ is 0.098. The calculated $\mathrm{r}(.894)$ is greater than the critical $\mathrm{r}$ (cal. $\mathrm{r} .893>$ crit. $\mathrm{r}$ 0.098), therefore, the research hypothesis is accepted.

\section{2) Hypotheses Two}

H1: There is a significant relationship existing between Employee Recognition and Job Satisfaction in the selected Public Universities in the South East Nigeria.

TABLE 4.5: CORRELATION ANALYSIS FOR EMPLOYEE RECOGNITION AND JOB SATISFACTION

\begin{tabular}{|c|c|c|c|}
\hline \multicolumn{4}{|c|}{ Correlations } \\
\hline & & EMPREC & $\begin{array}{l}J O B S A \\
T\end{array}$ \\
\hline \multirow[t]{3}{*}{ EMPREC } & Pearson Correlation & 1 & $.942^{* *}$ \\
\hline & Sig. (2-tailed) & & .000 \\
\hline & $N$ & 316 & 316 \\
\hline \multirow[t]{3}{*}{$J O B S A T$} & Pearson Correlation & $.942^{* *}$ & 1 \\
\hline & Sig. (2-tailed) & .000 & \\
\hline & $N$ & 316 & 316 \\
\hline
\end{tabular}

**. Correlation is significant at the 0.01 level (2-tailed).

Computation: SPSS Vs 20

Where:

EMPREC $=$ Employee Recognition

JOBSAT $=$ Job Satisfaction

Table 4.5 shows the correlation analysis for Employee Recognition and Job Satisfaction in the selected Public Universities in the South East. The result reveals that there is a very strong positive relationship existing between the variables $(r=.942)$.

TABle 4.6: SignificANCE TEST FOR HyPOTHESIS TwO

\begin{tabular}{lllll}
\hline \hline$N$ & Cal. $r$ & DF & Crit. $r$. & Remark \\
\hline 316 & .942 & 314 & 0.098 & Significant \\
\hline \hline
\end{tabular}

Table 4.6 shows the test of significance for hypothesis two. It showed that at .05 level of significance and at 314 degrees of freedom, that the critical $\mathrm{r}$ is 0.098 . Given that the calculated r .942 is greater than the critical r (cal. r .942 $>$ crit. $\mathrm{r}$ 0.098), the research hypothesis is therefore accepted.

\section{DISCUSSIONS AND FINDINGS}

From the first test of hypothesis, it was confirmed that there is a significant positive relationship existing between distributive justice and employee commitment in the selected public universities in the South East Nigeria. Thus, leading to the acceptance of the alternative hypothesis, what this result implies is that the more there is justice and fairness in the distribution or allocation of reward packages in the institutions, the more the employees will be committed to the organization. This result is consistent with the result of other researchers like [33], [12] and [24].

The second hypothesis was also tested empirically using correlation analysis and the alternative hypothesis was accepted following the revelation of the findings. It was revealed that there is a significant positive relationship existing between employee recognition and job satisfaction in the selected public universities in southeast Nigeria. The implication of this result is that employee recognition and job satisfaction of the employees go in one direction. That is, the more the recognition employees receive for better performance, the more they will be satisfied with their job and by extension the organization. This finding is corroborated by previous research of [43], [63] and [47].

\section{CONCLUSIONS AND RECOMMENDATIONS}

The study concludes that reward management practices have a significant positive relationship with the performance of employees in public universities studied in south-eastern Nigeria. This is due to the fact that all the decomposed variables of the reward management practices and the performance of the employees had significant positive relationships with each other (distributive justice and employee commitment, employee recognition and job satisfaction).

However, based on the findings of the study the following recommendations were made:

a) Public universities focused in the southeast should ensure that employees are fairly rewarded in that reward for all employees who perform similar jobs and at the same level; except when performance is used to measure the reward.

b) The institutions studied and their efforts do not only need to depend on the base salary earned by employees, but also instil various recognition programs such as awards, public compliments, bonuses and gifts for outstanding artists, as this will stimulate employees to work more and increase your level of job satisfaction.

\section{REFERENCES}

[1] J. S. Adams, "Towards an understanding of inequity," Journal of Animal and Social Psychology, vol. 67, pp. 422 - 432, 1963.

[2] J. S. Adams, Inequity in Social Exchange, San Diego: CA: Academic Press, 1965.

[3] E. K. Agbaeze, A. O. Agu, C.E. Onuoha, I. O. Etim, "Effect of Reward Management on Employee Performance of selected Oils and Gas Industries: Evidence from South-South Nigeria," International Journal of Management, IT \& Engineering, vol. 7, no. 5, pp. 18-33, 2017.

[4] V. Akafo, P. A. Boateng, "Impact of Reward and Recognition on Job Satisfaction and Motivation," European Journal of Business and Management, vol. 7, no. 24, pp. 112-124, 2015. 
[5] N. J. Allen, J. P. Meyer, "A cross-national perspective on managerial problems in a non western country," The Journal of Social Psychology, vol. 136, no. 2, pp. 165-172, 1990.

[6] H. Aquinis, Performance management, Pearson Prentice Hall; Upper Saddle River, New Jersey, 2007

[7] M. Armstrong, A Handbook of Human Resources Management Practice, $11^{\text {th }}$ ed, Kogan Page, London, 2009.

[8] M. Armstrong, Armstrong's Handbook of Human Resource Management Practice, New York, NY: Kogan Page Publishers, 2012.

[9] M. Armstrong, H. Murlis, Reward Management: A Handbook of Remuneration Strategy and Practice, London, Kogan Page Limited, 2007.

[10] M. Armstrong, S. Taylor, Armstrong's handbook of human resource management practice, Kogan Page Publishers, 2010.

[11] M. Armstrong, D. Brown, P. Reilly, Increasing the Effectiveness of Reward Management, Brighton, Institute for Employment Studies, 2009.

[12] R. Asim, S, Naveed, M. Kiran, F. Muhammad, F., Q. Faizan, "Effects of Organizational Justice on Organizational Commitment," International Journal of Economics and Financial Issues, vol. 6, no. 3, pp. 189-196, 2015 .

[13] H. J. Bernardin, J. E. A. Russell, Human Resource Management, Sixth Edition. New York: McGraw Hill, 2013

[14] J. Bratton, J. Gold, Human Resources Management: Theory and Practice, 3rd ed. New York: Palgrave Macmillan, 2003

[15] J. Bratton, J. Gold, Human resource management: Theory and practice, 4th ed. Basingstoke, Hampshire, UK: Palgrave Macmillan, 2007.

[16] D. Caruth, G. Handlogten, Managing Compensation and understanding it too, A Handbook for the perplexed, Westport CT, Quorum Books, 2001.

[17] R. Cropanzano, D. E. Bowen, W. Gilliland, "The Management of organizational justice," Academy of Management Perspectives, pp. 34 $-47,2007$.

[18] A. H. M. Elanain, "Testing the Direct and Indirect Relationship between Organizational Justice and Work Outcomes in a non-Western Context of the UAE," Journal of Management Development, vol. 29, no. 1 , pp. 5-27, 2010 .

[19] S. Fajana, Human Resource Management: An Introduction, Labofin and Company, Lagos, 2002.

[20] R. Folger, R. Cropanzano, Organizational Justice and Human Resource Management, Beverly Hills, CA: Sage, 1998.

[21] C. Gale, (2002). Encyclopaedia of Small Business: Employee Reward and Recognition Systems. [Online]. Available: http://www. answers.com/topic/employee-reward-and-recognition-systems

[22] B. Gibson, G. Cassar, "Longitudinal Analysis of Relationship between Planning and Performance in Small Firms," Small Business Economics, vol. 25, no. 3, pp. 207-222, 2005

[23] J. L. Gibson, J. I. M. Ivancevich, J. H. Donnely, Organization Behaviour, Structure, Processes, Boston: McGraw Hill, 1997.

[24] G. C. W. Gim, N. M. Desa, "The Impact of Distributive Justice, Procedural Justice, and Affective Commitment on Turnover Intention among Public and Private Sector Employees in Malaysia,' International Journal of Social Science and Humanity, vol. 4, no. 6 , pp. 487-492, 2014.

[25] A. Gostick, C. Elton, C. The Daily Carrot Principle: 365 Ways to Enhance Your Career and Life. New York: Simon \& Schuster, 2007.

[26] J. Greenberg, R. A. Baron, Behavior in Organization, 9th Edition, Prentice Hall, 2009.

[27] S. E. Gross, H. M. Friedman, "Creating an Effective Total Reward Strategy: Holistic Approach Better Supports Business Success," Benefit Quarterly, Third Quarter, vol. 20, no. 3, pp. 7-12, 2004.

[28] P. Hart, "Benefits of employee recognition in the workplace: reduced risk raised avenues", EHS Today, vol. 4, no. 2, pp. 49-52, 2011.

[29] J. Hashim, "Human resource development practices as determinant of HRD climate and quality orientation," Journal of European Industrial Training, vol. 30, no. 1, pp. 4-18, 2000

[30] O. Hatice, "The Influence of Intrinsic and Extrinsic Rewards on Employee Results: An Empirical Analysis in Turkish Manufacturing Industry," Business and Economic research Journal, vol. 3, no. 3, pp 29-48, 2012.

[31] I. M. Jawahar, "A Model of Organizational Justice and Workplace Aggression,” Journal of Management, vol. 28, pp. 811-834, 2002.

[32] Z. Jiang, Q. I. H. Xiao, L. Xiao, "Total Rewards Strategy: A Human Resources Management Strategy Going with the Trend of the Times,' International Journal of Business and Management, vol. 4, no. 11, pp. 177-184, 2009.

[33] R. Kanwal, A. R. Nosheen, Q. Mehwish, M. R. Adnan, "Relationship between Distributive, Procedural Justice and Organizational Commitment: An Empirical Analysis on Public Sector of Pakistan,'
Middle-East Journal of Scientific Research, vol. 16, no. 6, pp. 878 883, 2013.

[34] J. M. Keller, "Motivational systems", in: H. D. Stolovitch \& E. J. Keeps (Eds.), Handbook of Human Performance Technology (2nd ed.), San Francisco: Jossey-Bass/Pfeiffer, 1999, pp. 373-394.

[35] A. Kemboi, B. K. Geoffrey, C. J. Keter, "Intellectual Capital as an Antecedent to Employee Performance in Commercial Banks in Eldoret Town, Kenya," Developing Country Studies, vol. 4, no. 4, pp. $34-44,2014$.

[36] H. K. Kirunda, "Performance-based rewards and the performance of teachers in private secondary schools in Kampala District," MSc project, Makerere University, Uganda, 2010.

[37] I. Korir, D. Kipkebut, "The Effect of Reward Management on Employees Commitment in the Universities in Nakuru CountyKenya," Journal of Human Resource Management, vol. 4, no. 4, pp 37-48, 2016.

[38] R.V. Krejcie, D. W. Morgan, "Determining Sample Size for Research Activities," Educational and Psychological Measurement, vol. 30, pp. 607-610, 1970.

[39] E. Lawler, "What it means to treat people right," Ivey Business Journal, pp. 1-6, 2003.

[40] W. Lee, "The Relationship between Job Characteristics and Job Satisfaction toward Affective Commitment; The Case of Engineers in SepakatSetia Perunding SDN BHD”, Unpublished MBA Project, University Sains Malaysia, 2010

[41] R. C. Mahaney, A. C. Lederer, "The Effect of Intrinsic and Extrinsic Rewards for Developers on Information Systems Project success,' Project Management Journal, vol. 37, no. 4, pp. 42-54, 2006

[42] P. Mahender, "Employees' Reward Management Practices in Corporate Sector (Review Paper)," View of Space International Multidisciplinary Journal of Applied Research, vol. 1, no. 9, pp. 8699, 2013.

[43] S. I. Mbah, G. C. Mgbemena, D. C. Ejike, "Effective Reward Management and Employee Performance in Civil Service (A Study of Anambra State Civil Service)," European Journal of Business and Management, vol. 7, no. 27, pp. 134-152, 2015.

[44] G. Milkovich, J. Newman, Compensation, 7th ed. Homewood, IL. McGraw-Hill Higher Education, 2002.

[45] J. S. Muhammad, R. Musawwir, A. Gulnaz, Z. Huma, R. Adnan, "Job Satisfaction and Motivation of Teachers of Public Educationa Institutions," International Journal of Business and Social Science, vol. 3, no. 8, pp. 271-281, 2012.

[46] O. H. Ndede, "Effects of Reward Management on Employee Performance in Hotels in North Coast, Kenya," Research Project Submitted in Partial Fulfilment of the Requirements for the Award of the Degree of Master of Business Administration (MBA), School of Business; University of Nairobi, 2014.

[47] D. N. Ndungu, "The Effects of Rewards and Recognition on Employee Performance in Public Educational Institutions: A Case of Kenyatta University, Kenya," Global Journal of Management and Business Research, vol. 17, no. 1, pp. 43-68, 2017.

[48] B. Nelson, 1001 Ways to Reward Employees, 2nd ed., New York: Workman Publishing, 2005.

[49] B. Nelson, D. R. Spitzer, The 1001 Rewards \& Recognition Field Book: The Complete Guide, New York: Workman Publishing Company, 2002.

[50] W. Njanja, R. Maina, K. Njagi, "Effect of Reward on Employee Performance: A Case of Kenya Power and Lighting Company Ltd Nakuru, Kenya," International Journal of Business and Management, vol. 8 , no. 21, pp. 41-49, 2013.

[51] I. E. Okoli, P. N. Nwakoby, A. Ihediwa, "Organizational Climate and Affective Commitment: Evidence from Private Tertiary Institutions,' International Journal of Scientific \& Technology Research, vol. 9, no. 3, pp. 656-662, 2020.

[52] I. E. Okoli, K. C. Okeke, C. M. Nuel-Okoli, "Conflict Management and Employee Commitment among Academic Staff in Public Universities in South East, Nigeria," International Journal of Advanced Academic and Educational Research, vol. 13, no. 2, pp. 84103, 2017.

[53] I. E. Okoli, "Organizational Climate and Job Satisfaction among Academic Staff: Experience from Selected Private Universities in Southeast Nigeria," International Journal of Research in Business Studies and Management, vol. 5, no. 12, pp. 36-48, 2018.

[54] P. Pratheepkanth, "Reward System and Its Impact on Employee Motivation in Commercial Bank of Sri Lanka Plc, In Jaffna District,' Global Journal of management and business research, vol. 11, no. 1, 2011.

[55] S. Robbins, T. Judge, Organizational Behaviour, 12th ed., New Jersey: Prentice Hall, Inc, 2008. 
[56] L. R. Roshan, "The Relationship between Rewards, Recognition and Motivation at Insurance Company in the Western Cape," Dissertation Submitted in Partial Fulfilment of the Requirements for the award of a Master's Degree of Magister Commerce in the Department Of Industrial Psychology, University of Western Cape Town, 2005.

[57] Roshna \& Rohan, "Analyzing Role of Reward Management System on Managing Employee Performance Effectively: Study with reference to Co-operative Sugar factories in Pune, Maharashtra," Chronicle of the Neville Wadia Institute of Management Studies \& Research, 46-53, 2016.

[58] S. Rynes, B. Gerhart, Compensation in organizations: Current research and practice, San Francisco, CA: Jossey-Bass, 2000

[59] J. Schermerhorn, J. Hunt, R. Osborn, Organizational Behaviour, 9th Edition, John Willey \& Sons, Inc., 2002.

[60] S. Tangthong, "A causal model of compensation and benefits and reward management on organizational effectiveness of MNCs," Asian Journal of Management Research, vol. 5, no. 1, pp. 44-66, 2014.

[61] P. Thompson, Total Reward, Chartered Institute of Personnel and Development, London, 2002.

[62] H. Turinawe, "Reward Systems, Job Satisfaction, Organizational Commitment and Employee Performance in Public Higher Institutions of Learning in Uganda," Dissertation Submitted to Makerere University Business School is Partial Fulfilment of the Requirements for the award of a Master's Degree of Human Resource Management of Makerere University, 2011.

[63] D. Tuvei, D. Wanjere, H. Mauyo, "Influence of Intrinsic Rewards on Organizational Performance in Sugar Companies of Western Kenya," International Journal of Science and Technology, vol. 6, no. 10, 2016.

[64] G. A. Yukl, Leadership in Organizations, 5th Edition, Prentice Hall, Upper Saddle River, 2002. 